\title{
THE EFFECT OF DIFFERENT SUBSTRATES ON TRITERPENOIDS AND FATTY ACIDS IN FUNGI OF THE GENUS Pleurotus
}

\author{
IVONNE J. NIETO*, CAROLINA CHEGWIN A.
}

\author{
Dr. Ivonne Jeannette Nieto, Chemistry Department, National University of Colombia, Bogotá Campus, Ciudad Universitaria, \\ Carrera 30 No. 45-03, Edificio 451 Laboratorio 210. Bogotá-Colombia.
}

(Received: April 18, 2012 - Accepted: October 8, 2012)

\begin{abstract}
Three species of cultivated fungi of the genus Pleurotus, $P$. pulmonarius, $P$. sajor-caju, and $P$. ostreatus, were studied to determine the effect of different substrates on their production of fatty acids and secondary metabolites. It was discovered that the substrate had a marked influence on fungal composition by promoting the production of a more diverse variety of compounds or by increasing their content. Fungi cultivated on substrates containing cacao shells demonstrated an increased biosynthesis of triterpenoids with greater structural diversity. Their content, however, was less than that obtained using cereal residue substrates.

The species P. ostreatus had the highest triterpenoid content, followed by P. pulmonarius and, finally, P. sajor-caju.
\end{abstract}

Keywords: Fungi, triterpenoids, fatty acids, Pleurotus, substrate.

\section{INTRODUCTION}

Mushrooms have greatly varied and important uses throughout the world, such as for food, tonics, and drugs ${ }^{1,2}$. Mushrooms have been used in recent decades for the bioconversion of organic waste materials because their large enzymatic pool allows them to develop in many substrates, thus greatly benefits both humans and the ecosystem. Many mushrooms have properties that allow them to be used as nutraceuticals; that is, they produce compounds that can be extracted for use as antitumoral and hypocholesterolemic agents and as immunological modulators. This fact has awakened the interest of the scientific community in studying the secondary metabolites responsible for these properties. These products are biosynthesized from primary metabolites and are the end products of the metabolism of natural products; therefore, secondary metabolites are restricted to certain organisms. Lipids, a broad group of molecules that includes fatty acids, sterols, sphingolipids, and phospholipids, are the most important metabolic energy source, as they comprise the structural and functional components of biomembranes in different organisms. Unsaturated fatty acids, which belong to this group of compounds, have various positive health effects, such as antioxidant activity, colon cancer inhibition, and cardioprotective effects ${ }^{3}$ With respect to compounds of triterpenoidal type within sterols found, ergosterol micosterol is of great importance, as it is a synthetic precursor to both vitamin D2 (ergocalciferol) and vitamin D3 (cholecalciferol) with equal potency and are metabolized to form a hormone known as calcitriol. This hormone plays a key role in the metabolism of calcium and phosphorus ${ }^{4}$. Further beneficial effects for this group of compounds have been reported and include antihyperlipidemic, anti-inflammatory, antioxidant, and both bacterial and fungal growth inhibitory activities ${ }^{5}$. The use of sterols has been found to cause a hypocholesterolemic effect by competing with cholesterol for absorption by the intestine. In this way, the antiatherosclerotic and anticarcinogenic properties of fungi have been specifically studied in both animal models and cellular systems with very promising results ${ }^{6-8}$.

Fungi belonging to the genus Pleurotus are the second most highly produced worldwide and represent approximately $25 \%$ of the group known as the "big six mushrooms", which are the most widely produced mushrooms, with China as the primary source ${ }^{9}$. Basidiomycetes can use the greatest number of different substrates for cultivation ${ }^{10}$, which is why they have been the subject of broad research that generally mentions their nutritional quality and the effect of substrate variation on the primary metabolites that are directly related to the nutritional quality ${ }^{11-15}$.

Pleurotus cultivation has the advantage of being cultivable in tropical climates, simple to produce, and compatible with organic substrates rich in lignin and cellulose, such as rice straw, sugarcane bagasse, coffee pulp, cocoa waste, and dry grass ${ }^{16}$. It should be highlighted that Colombia, being a tropical and purely agricultural country, generates a wide variety of waste residues that are used for fungi cultivation, which creates a clear need to investigate the influence of the substrate on the secondary metabolites.

In this study, we report the first results relating to the effect of substrate variation on the triterpenoid metabolites and fatty acids present in three
Pleurotus species grown on different substrates. We aim to determine which substrate yields a product that can be used as a natural source for these compounds, which have demonstrated significant bioactivity.

\section{EXPERIMENTAL}

Names were given to the fungi used for this research according to their species: PO to P. ostreatus, $\mathbf{P P}$ to P. pulmonarius, and PSC to P. sajor-caju. Numbers were assigned based on the substrate used based on the following system:

PO1 was grown using a mixture of $17 \%$ bran, $35 \%$ sawdust, $3.0 \% \mathrm{CaCO}_{3}$, $43 \%$ chips, and $2.0 \%$ molasses and was facilitated by the Seeds of the Future Women Association (named AMUSEF according to its Spanish initials). PO2 was grown using a mixture of $50 \%$ sugarcane, $30 \%$ beans, and $20 \%$ cocoa shells. PO3 was grown using $16.8 \%$ bean stems and pods, $18.6 \%$, maize calyx stems and leaves, $52.2 \%$ rice husks, $9.7 \%$ rice hulls, and $2.7 \% \mathrm{CaCO}_{3}$. PP1 was grown using $50 \%$ sugarcane bagasse, $25 \%$ corn husks, and $25 \%$ bean chaff. PP2 was grown using $50 \%$ bagasse, $30 \%$ bean chaff, and $20 \%$ cocoa shells and was provided by the Association of Fungi Producers of Colombia ASOFUNGICOL. For species $P$. sajor-caju, PSC1 was cultivated on zoca and PSC2 was cultivated on a mixture of zoca and coffee pulp. Both of these fungi were provided by the National Center for Coffee Research CENICAFE.

A $10 \mathrm{~g}$ sample of each lyophilized and milled fungus was taken and subjected to maceration with $30 \mathrm{ml}$ of methanol for eight days, removing the solvent daily.

The crude methanol extracts were concentrated to dryness on a rotary evaporator followed by an extraction using $\mathrm{CH}_{2} \mathrm{Cl}_{2}: \mathrm{H}_{2} \mathrm{O}(1: 1)$. Each of these extracts was characterized by GC-MS using a Hewlett Packard 6890 gas chromatograph with the following characteristics: HP5 30 m capillary column with an inside diameter of $0.33 \mathrm{~mm}$ and $25 \mathrm{~mm}$ thick; helium carrier gas with a flow of 4.5 to $1 \mathrm{ml} / \mathrm{min}$; the $1: 10$ split mode; the temperature was ramped from $90^{\circ} \mathrm{C}$ to $300^{\circ} \mathrm{C}$ at $5^{\circ} \mathrm{C} / \mathrm{min}$. The gas chromatograph was coupled to a 5973 mass spectrometer with a $70 \mathrm{eV}$ ionization source. The injection volume in all cases was $1 \mu \mathrm{l}$ with a concentration of $1 \mathrm{mg} / \mathrm{ml}$. The major components for each extract were identified via the analysis of their fragmentation patterns in the mass spectra by comparing our values to the literature ${ }^{172}$. The quantity of fatty acids and esters was determined by their relative areas, and the sterol content was measured via the Liebermann-Burchard colorimetric method using a stigmasterol calibration curve with a concentration range between $0.071 \mathrm{mg} /$ $\mathrm{ml}$ and $0.71 \mathrm{mg} / 23 \mathrm{ml}$ and consisting of nine levels ${ }^{22}$.

\section{RESULTS AND DISCUSSION}

The chromatographic analysis of the three species was performed individually, and the comparisons were performed afterwards. Two distinct zones were clearly visible in the chromatograms (chromatograms No. 1, 2, and 3): one between 0 and 6 minutes corresponded to fatty acids and esters, and another between 16 and 30 minutes corresponded to triterpenes and triterpenoids. 
Table 1 shows the components and concentrations of the fat fraction. This analysis reveals that the composition changes depend on the species, which is the most obvious for the structural variation. $P$. ostreatus had the greatest variation (table 1), followed by P. pulmonarius and, finally, $P$. sajor-caju.

Table 1. Fat composition for P. ostreatus, P. pulmonarius, and P. sajor-caju cultivated on different substrates.

\begin{tabular}{|l|c|c|c|c|c|c|c|}
\hline Component & \multicolumn{7}{|c|}{ Pleurotus species $^{a}$} \\
\hline & PO1 & PO2 & PO3 & PP1 & PP2 & PSC1 & PSC2 \\
\hline 1. Pentadecanoic acid & 0.8 & & 0.8 & 9.4 & & 0.2 & 0.2 \\
\hline 2. Palmitic acid & 10.1 & 9.3 & 11.0 & 18.4 & 18.1 & 5.1 & 7.9 \\
\hline 3. Linoleic acid & 18.2 & 19.1 & 18.3 & & 9.7 & 13.3 & 13.5 \\
\hline 4. Stearic acid & & & 0.7 & 8.3 & & & \\
\hline 5. Oleic acid & & & & 8.0 & & & \\
\hline 6. Methyl hexadecanoate & & 4.2 & 0.3 & & 10.1 & & \\
\hline 7. Ethyl hexadecanoate & & 2.4 & & & & 3.6 & 5.2 \\
\hline 8. Methyl 8,11-octadecadienoate & & 12.5 & & & 19.7 & & \\
\hline 9. Ethyl linoleate & & 15.5 & 4.1 & & & 10.5 & 12.2 \\
\hline TOTAL & 29.1 & 63.0 & 35.2 & 44.1 & 57.6 & 32.7 & 39.0 \\
\hline
\end{tabular}

a. The amounts are given as percentages calculated based on the total ion chromatogram (TIC) results.

The influence of the substrate on the composition of the studied fractions was clearly shown. This observation is consistent with the chemical composition analysis performed by our research group for the same mushrooms, which found that the highest concentration of fat soluble in petroleum ether corresponded to $P$. ostreatus ${ }^{15}$. Such behavior was due to the substrate effects because one of the components was the cocoa shell, which has a relatively high fat content ${ }^{23}$. The next most diverse species in terms of the variety of components was $P$. pulmonarius, which also varied in fat composition, with PP2 possessing the highest content for both the total concentration and the variety of compounds present. Similarly, this variation substrate-dependent and was also cultivated using cocoa shell.

Chromatogram 1. Comparative study of the $\mathrm{CH}_{2} \mathrm{Cl}_{2}$ extracts from $P$. ostreatus grown on different substrates.

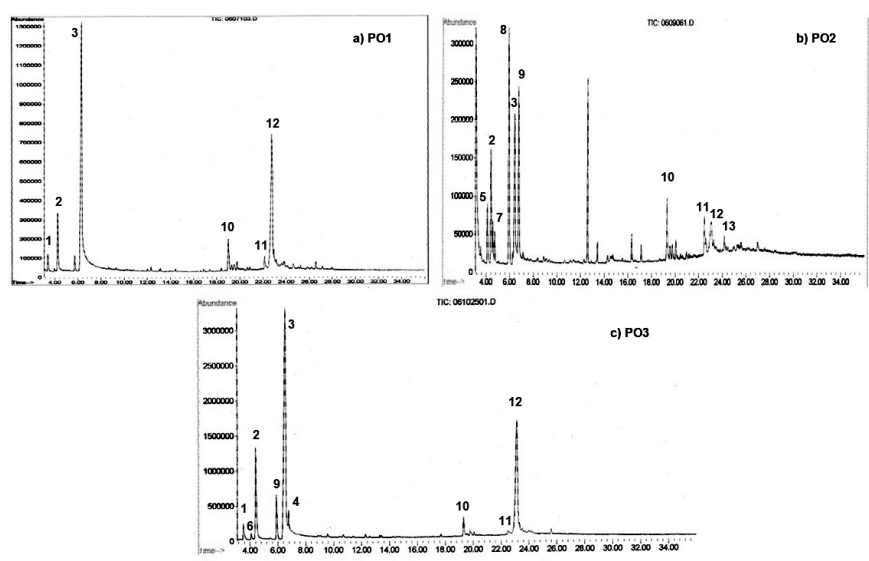

a). PO1 P. ostreatus was cultivated using a mixture of $17 \%$ bran, $35 \%$ sawdust, $3.0 \% \mathrm{CaCO}_{3}, 43 \%$ chips, and $2.0 \%$ molasses. b) PO2 P. ostreatus was cultivated using a mixture of $50 \%$ sugarcane, $30 \%$ beans, and $20 \%$ cocoa shells. c) PO3 P. ostreatus was grown using $16.8 \%$ bean stems and pods, $18.6 \%$ maize calyx stems and leaves, $52.2 \%$ rice husks, $9.7 \%$ rice hulls, and $2.7 \% \mathrm{CaCO}_{3}$

Chromatogram 2. Comparative study of the $\mathrm{CH}_{2} \mathrm{Cl}_{2}$ extracts of $\mathrm{P}$. pulmonarius grown on different substrates.

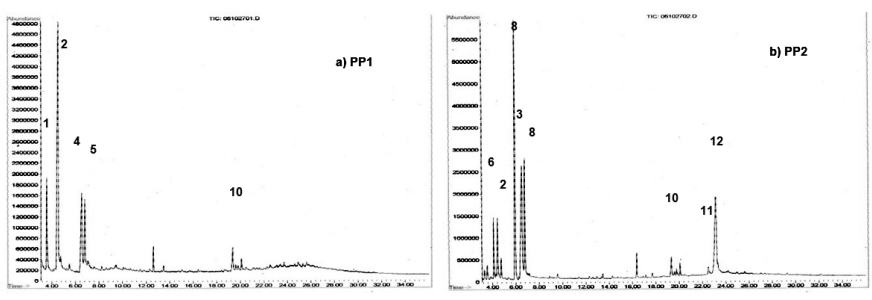

a) PP1 P. pulmonarius was cultivated using 50\% sugarcane bagasse, $25 \%$ corn husks, and $25 \%$ bean chaff. b) PP2 P. pulmonarius was cultivated using $50 \%$ sugarcane bagasse, $30 \%$ bean chaff, and $20 \%$ cocoa shells.

The substrate influence was similar for $P$. sajor-caju cultivated on zoca and a zoca-pulp mixture (chromatograms $3 \mathrm{a}$ and $3 \mathrm{~b}$ ); i.e., the fat composition was similar in both the quantity and type of compounds, which was fully consistent with their similar substrate compositions. The peak that appeared at a $t_{r}$ of 3.96 min for PSC2 (chromatogram 3b) corresponds to caffeine incorporated into the fungus from the substrate used for cultivation. This feature had already been reported during other research within this group and is not common to all fungi ${ }^{24}$.

Chromatogram 3. Comparative study of the $\mathrm{CH}_{2} \mathrm{Cl}_{2}$ extracts of $P$. sajorcaju cultivated on different substrates.

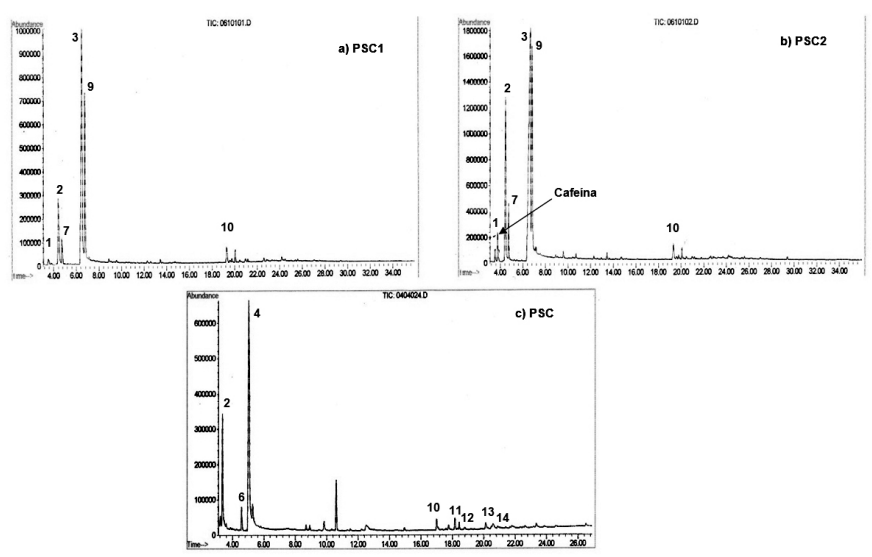

a) PSC1 was $P$. sajor-caju cultivated using zoca. b) PSC2 was cultivated using zoca and coffee pulp. c) PSC3 was cultivated using coffee pulp.

The $P$. ostreatus species had the highest overall fat content. This species had a higher fat content when cultivated on cocoa shell than for the other substrates. The substrates used for PO1, PO3, and PP1 favored the production of unsaturated fatty acids rather than esters, and both cocoa and coffee industry wastes produced similar quantities of these compounds, especially for cases 
such as PP2.

Table 2 summarizes the chromatographic analyses and mass spectral of peaks of interest for the triterpenoid fractions. Table 3 shows the results of the dichloromethane extracts with the sterol percentages calculated for each case. No significant variation was observed in the obtained extract percentage, contrary to what occurred for the sterol content.

Table 2. Triterpenoid compositions of $P$. ostreatus, P. pulmonarius, and P. sajor-caju grown on different substrates.

\begin{tabular}{|c|c|c|c|c|c|c|c|c|}
\hline \multirow[t]{2}{*}{ Component } & \multicolumn{8}{|c|}{ Pleurotus ${ }^{\text {a }}$ Species } \\
\hline & $\mathrm{RT}(\min )$ & PO1 & $\mathrm{PO} 2$ & PO3 & PP1 & PP2 & PSC1 & $\mathrm{PSC} 2$ \\
\hline 10. Ergost-2,5,7,9(11),22-pentaene & 19.25 & 3.1 & 5.3 & 2.8 & 2.7 & 2.7 & 1.6 & 1.8 \\
\hline 11. Ergost-5,7,9(11),22-tetraen-3 $\beta$-ol & 22.36 & 11.3 & 2.5 & 0.7 & & 0.9 & & \\
\hline 12. Ergost-5,7,22-trien-3 $\beta$-ol & 22.83 & 0.3 & 3.5 & 9.5 & & 5.6 & & \\
\hline 13. Ergost-7-en-3 $\beta$-ol & 24.02 & & 0.2 & & & & & \\
\hline
\end{tabular}

a. The amounts are given as percentages calculated based on the TIC results.

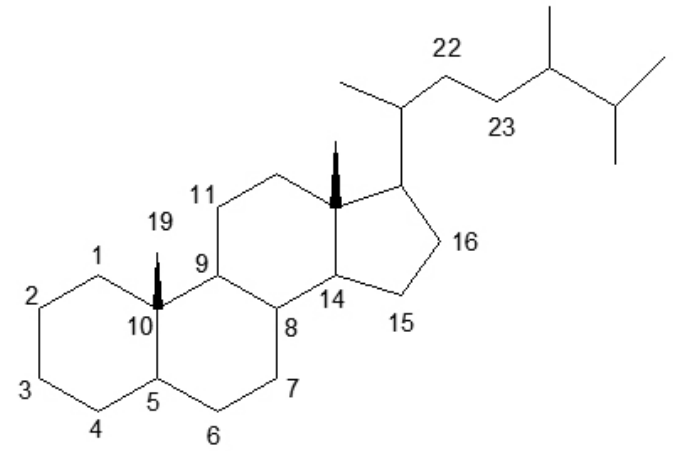

Table 3. Extract quantity and sterol content obtained from $P$. ostreatus, $P$. pulmonarius, and $P$. sajor-caju grown on different substrates using dichloromethane.

\begin{tabular}{|l|c|c|}
\hline Pleurotus Species & Extract Quantity (\%) & Sterol Content (\%) \\
\hline PO1 & 9.80 & 17.3 \\
\hline PO2 & 9.75 & 15.6 \\
\hline PO3 & 9.60 & 18.4 \\
\hline PP1 & 9.56 & 9.5 \\
\hline PP2 & 9.67 & 13.2 \\
\hline PSC1 & 9.85 & 8.7 \\
\hline PSC2 & 9.34 & 7.8 \\
\hline
\end{tabular}

Chromatogram 1 shows the profiles for the three studied P. ostreatus, and PO2 showed the greatest triterpenoid structural variations and fat content. However, the triterpenoidal structural variations were smaller and their proportions greater for $\mathrm{PO1}$ and $\mathbf{P O 3}$, which had very similar chromatographic profiles. This behavior is not easily explained, as the substrates on which these species were cultivated had different compositions and seemed to be characteristic of the species. The results presented for PO2 indicate that the use of cocoa shells favors the biosynthesis of these compounds; therefore, its inclusion in the substrate would help to increase the production of these fungal compounds, which have been shown to possess extensive medicinal properties 25,26 .

Another obvious difference between the three studied P. ostreatus groups was their ergosterol content relative to PO2, for which the primary component is triterpene [10]. This variation could lead to the use of the culture for substrates PO1 and PO3 when the enrichment of ergosterol is desirable, such as for the production of vitamin $\mathrm{D} 2$; the species $P$. ostreatus had the highest production of this vitamin relative to the other basidiomycetes ${ }^{27}$ upon UV irradiation using $366 \mathrm{~nm} 254$ y wavelengths ${ }^{28}$.

The effect of substrate variation and the impact of cocoa shells on the triterpenoid biosynthesis were most evident in mushrooms with lower triterpenoid content. Such is the case with P. pulmonarius, as indicated by the

\section{[10] Ergost-2,5,7,9(11),22-pentaene [11] Ergost-5,7,9(11),22-tetraen-3ß-ol [12] Ergost-5,7,22-trien-3ß-ol

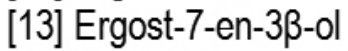

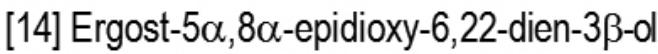

chromatographic profile and the data shown in Table 2 and strengthened by the data collected for P. sajor-caju. However, in terms of nutritional quality and crop efficiency ${ }^{29}$, the use of waste from the coffee industry is an excellent alternative. Comparing the profiles of PSC1 and PSC2 to PSC cultivated using only coffee pulp (chromatogram $3 \mathrm{c}$ ) ${ }^{16}$ indicates that the increased triterpenoid component in $P$. sajor-caju is possibly caused by the nature of the substrate and directly relates to the addition of the pulp in proportions above $50 \%$ and not to the species itself.

\section{CONCLUSIONS}

Of the mushrooms studied, the $P$. ostreatus species had the highest triterpenoid content, followed by $P$. pulmonarius and $P$. sajor-caju. The substrate directly influenced the composition of the fungus, which indicated that cocoa shells would be an ideal substrate for promoting greater variation in the biosynthesis of these compounds if the objective was to obtain a nutraceutical. If, however, the goal is to obtain a product with high ergosterol content, the use of cereals would be a better alternative. While all of the reported compounds were identified as forming a fat soluble fraction in Pleurotus $4,6,30,31$, this is the first report where this production is assessed by varying the cultivation substrate. The results from this study are consistent with reports that, while not focused on the production of fatty acids and triterpenes, corroborate the observed changes. For example, upon incorporation of cotton seeds or rice husks in the substrate, protein content, free amino acids, and the total lipid content were increased in $P$. florida, while there was a decrease in total dietary fiber and polymeric carbohydrate levels. Both $P$. ostreatus and $P$. sajor-caju have higher ash contents when grown using rice husks rather than banana straw, and P. sajor-caju has a higher moisture levels and fiber content when using rice straw ${ }^{10}$. Other studies have yielded similar results, although they always focused on changes in the nutritional quality ${ }^{12,32,33}$, biological efficiency, ${ }^{29,34-36}$ and enzyme production ${ }^{37,38}$.

\section{ACKNOWLEDGMENTS}

The authors wish to thank the Department of Chemistry and the Research Division of the National University of Colombia in Bogota. 


\section{REFERENCES}

1. Rathee S, Rathee D, Rathee D, Kumar V, Rathee P, Rev. Bras. Farmacogn, 22, 459, (2012).

2. Wasser SP, Appl Microbiol Biotechnol 89, 1323, (2011).

3. Miles. P.G CST. Biología de las setas. Fundamentos básicos y acontecimientos actuales. Singapore, New Jersey; 1998.

4. Wasser SP, Wells AL, Int J Med Mushrooms, 1, 31, (1999).

5. Tang Y, Li Y-Y, Li H-M, Wan D-J, Tang Y-J, J. Agric. Food. Chem, 59, 4736, (2011).

6. Savón RCB, Fernández CD, Manrique CEM, Sevilla EIR, Quevedo HJM, Rev Cubana Aliment Nutr, 16, 13, (2002).

7. Tang Y, Li H-M, Tang Y-J, Food Chem, 132, 1207, (2012).

8. Phillips KM, Ruggio DM, Horst RL, Minor B, Simon RR, Feeney MJ, et al., J. Agric. Food. Chem, 59, 7841, (2011).

9. Kim YJ, Park J, Min BS, Shim SH, J. Korean. Soc. Appl. Bi, 54, 287, (2011).

10. Tewtrakul S, Tansakul P, Daengrot C, Ponglimanont C, Karalai C, Phytomedicine 17, 851, (2010).

11. Gregori A, Svagelj M, Pohleven J, Food. Technol Biotech, 45 238, (2007).

12. Petrovska BB, Kulevanova S, Jordanoski B, Stefov V, Nutr. Food. Sci, 31, 242 (2001).

13. Shashirekha MN, Rajarathnam S, Bano Z, Food Chem, 92, 255, (2005).

14. Fasidi IO, Ekuere UU, Food Chem, 48, 255, (1993).

15. Yang J-H, Lin H-C, Mau J-L, Food Chem, 72 465, (2001).

16. Nieto IJ, Chegwin A C, Rev. Col. Biotec, 12, 169, (2010).

17. Rodríguez-Valencia N, Gómez-Cruz F, Avances técnicos Cenicafé, 285, $7,(2001)$.

18. Nieto R IJ, Valencia M, Bol. Soc.Chil, 47, 511, (2002).

19. Yaoita Y, Amemiya K, Ohnuma H, Furumura K, Masaki A, Matsuki T, et al., Chem. Pharm. Bull, 46, 944, (1998).

20. Gunatilaka AAL, Gopichand Y, Schmitz FJ, Djerassi C, J. Org. Che, 46, 3860, (1981).

21. Barrero AF, Oltra JE, Poyatos JA, Jiménez D, Oliver E, J. Nat. Prod., 61, 1491, (1998).
22. Barrero AF, Oltra JE, Robinson J, Burke PV, Jiménez D, Olivera E, Steroids 67, 403, (2002).

23. Syed Mubbasher S, Imran H, Syed Dilnawaz A, Pakistan Journal of Nutrition, 2, 178, (2003).

24. Bernal. I. Análisis de alimentos. Bogotá- Colombia; 1998.

25. Nieto R IJ, Chegwin A C, Osorio Z HJ, Rev. Iberoam. Micol, 24, 72, (2007).

26. A. Trigos CM. Hongos comestibles cultivados como fuentes potenciales de ergosterol. Aspectos generales sobre biología de hongos. In: Rivera A editor. Hongos comestibles cultivados como fuentes potenciales de ergosterol. Aspectos generales sobre biología de hongos. Bogotá D.C: Colciencias; 1998.

27. Jasinghe VJ, Perera CO, Sablani SS, J. Food. Eng, 79, 864, (2007).

28. Teichmann A, Dutta PC, Staffas A, Jagerstad M, LWT-Food Sci. Technol, 40, 815, (2007)

29. Salmones D, Mata G, Waliszewski KN, Bioresour. Technol, 96, 537, (2005).

30. Yaoita Y, Yoshihara Y, Kakuda R, Machida K, Kikuchi M, Chem. Pharm. Bull, 50, 551, (2002).

31. Gil-Ramirez A, Clavijo C, Palanisamy M, Soler-Rivas C, Ruiz-Rodriguez A, Marín FR, et al. Edible mushrooms as potential sources of new hypocholesterolemic compounds. Edible mushrooms as potential sources of new hypocholesterolemic compounds. 2011:110.

32. Silva SO, Costa SMGd, Clemente E, Braz. Arch. Biol. Techn, 45, 531, (2002).

33. Tisdale TE, Miyasaka SC, Hemmes DE, World J. Microb. Biot, 201, (2006).

34. Pant D, Reddy UG, Adholeya A, World J. Microb. Biot, 22, 267, (2006).

35. Estrada AER, Royse DJ, Bioresour Technol, 98, 1898, (2006).

36. Mandeel QA, Al-Laith AA, Mohamed SA, World J. Microb. Biot, 21, 601, (2005).

37. Sainos E, Díaz-Godínez G, Loera O, Montiel-González A, Sánchez C, Appl. Microbiol. Biotechnol, 72, 812, (2006).

38. Elisashvili V, Penninckx M, Kachlishvili E, Asatiani M, Kvesitadze G, Enzyme. Microb. Technol, 38, 998, (2006). 